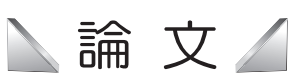

Original Paper

\section{赤色頁岩のせん断強度の \\ ばらつきに関する一考察 *}

$\begin{array}{lllllll}\text { 大 保誠介 }{ }^{1} & \text { 湯 } & & \text { 楊 }^{2} & \text { 許 } & & \text { 江 }^{3} \\ & \text { 羽 柴 公 } & \text { 博 }^{4} & \text { 福 井 勝 } & \text { 則 }^{5}\end{array}$

\title{
Variation in the Shear Strength of Red Shale
}

\author{
by Seisuke OKUBO ${ }^{\mathrm{a}}$, Yang TANG ${ }^{\mathrm{a}}$, Jiang XU' ${ }^{\mathrm{a}}$, Kimihiro HASHIBA ${ }^{\mathrm{b} *}$ and Katsunori FUKUI ${ }^{\mathrm{b}}$
}

a. College of Resources and Environmental Science, Chongqing University, Chongqing, 400044, China

b. Department of Systems Innovation, The University of Tokyo, 7-3-1, Hongo, Bunkyo-ku, Tokyo, 113-

8656, Japan (*Corresponding author, E-mail: hashiba@sys.t.u-tokyo.ac.jp)

\begin{abstract}
Variation of rock strength has an important role in designing the various rock structures. Though strength in uniaxial stress state such as uniaxial compressive strength has been well investigated up to now, the strength in complicated stress state such as triaxial compressive or shear strength has been studied only to very limited extent because of its difficulty in experimental works. For example, variation of shear strength should be studied under various normal stresses and then many specimens are necessary. In this study, direct shear tests of red shale were conducted under the normal stress from 1 to $6 \mathrm{MPa}$. A special care was taken to make as many specimens as possible from the limited sample rock, and total number of 397 specimens were tested. It was found that the variation of $\Delta \tau$, which is the difference between the shear strengths measured in testing and calculated with the regression line, did not depend on normal stress. The obtained failure criterion and variation of strength for the red shale were discussed comparing the envelope of rock stress which was reported previously and the results of other rocks in various testing conditions.
\end{abstract}

KEY WORDS: Rock, Shear Strength, Cohesion, Internal Friction, Failure Criterion

\section{1. は じめに}

岩石の強度が著しくばらつくことは, よく知られている ${ }^{1)}$ 。岩 石の強度のばらつきを把握することは，岩盤構造物の設計の立場 から極めて重要である ${ }^{2)}$ 。しかし, 一軸圧縮強度や圧裂引張強 度については, 従来から多くの研究がなされてきているが 3-7), 周圧下での圧縮強度 ${ }^{8)}$ やせん断強度については, これまでの知 見は十分ではない。周圧下では周圧の影響を考慮しなければなら ないし，せん断強度では垂直応力の影響を考慮せねばならず9), よって 2 次元の確率分布関数を考えざるを得ないために, 実験的 にも解析的にも困難があるためといえよう。

著者らは岩石の圧縮強度 (一軸, 三軸) と引張強度 (一軸, 圧裂) のばらつきについて検討した ${ }^{10)}$ 。その際に, 周圧下での圧縮強 度についても検討したが，はっきりした確率分布を得るには，可 能な限り多くの試験をすることが必要なことを示した。一方, 鉱 山の開発予定地などで採取される岩石ブロックやボーリングコア については, 実験室実験で用いる試験片を精度よく, かつ表面に

*2014 年 5 月 19 日受付 2014 年 7 月 14 日受理

1. 正会員 工博 重慶大学 教授資源及環境科学学院

2. 重慶大学資源及環境科学学院

3. $\mathrm{PhD}$ 重慶大学教授資源及環境科学学院

4. 正会員工博東京大学 講師工学系研究科システム創成学専攻

5. 正会員工博 東京大学教授 工学系研究科システム創成学専攻

[ 著者連絡先 ] FAX: 03-3818-7492 (東大・システム創成)

E-mail: hashiba@sys.t.u-tokyo.ac.jp

キーワード : 岩石, せん断強度, 粘着力, 内部摩擦角, 破壊条件
久けのないように製作することは難しい場合が多い。しかしなが ら，そのような場合にこそ，岩石の物性值やばらつきの把握が重 要となる。

本研究では, Shin et al. ${ }^{10)}$ で検討しなかったせん断強度のばら つきを，一面せん断試験により検討することにした。より多くの 試験を実施するために, 円柱形の岩石コアを実験室で抜いた後に, 岩石コアよりも少し大きめの型枠中に入れてから, 型枠にモルタ ルを流し込んで全体をかためることにした。こうすることによつ て，多くの試験を実施することが可能となった。また，試験片の 作成にこのような工夫をすることによって，あらかじめ圧裂引張 試験によって亀裂をいれた試験片を試験することも可能となっ た。また, 気乾状態の試験の他に湿潤状態の一面せん断試験もお こなったので検討する。

\section{2. 試料岩石と試験方法}

試料岩石はニジェール産白亜紀赤色頁岩である。資源開発を業 務の一環とする企業より, 赤色頁岩のボーリングコアの提供を受 ける機会があった。ボーリングコアはかなりの量で, 採取現場の 力学特性は比較的均一であるとの説明を受けたので, この岩石で 試験を行うことにした。一面せん断試験に先立って一軸圧縮試験 と圧裂引張試験を実施した。その結果をTable 1 に示す。ここで, $50 \%$ 接線ヤング率とポアソン比とは, 一軸圧縮試験片に歪ゲー ジを貼り付けて測定したものである。

せん断試験に使用する試験片の作成について以下で説明する。 
Table 1 Summary of uniaxial compression and indirect tension tests.

\begin{tabular}{|c|c|c|c|c|c|c|}
\hline Test & $\begin{array}{c}\text { Specimen } \\
\text { diameter } \\
(\mathrm{mm})\end{array}$ & $\begin{array}{c}\text { Specimen } \\
\text { length } \\
(\mathrm{mm})\end{array}$ & $\begin{array}{l}\text { Number of } \\
\text { specimen }\end{array}$ & $\begin{array}{c}\text { Strength } \\
\text { Ave (MPa) } \\
\text { CV }\end{array}$ & $\begin{array}{c}E \\
\text { Ave }(\mathrm{GPa}) \\
\mathrm{CV}\end{array}$ & $\begin{array}{c}v \\
\text { Ave } \\
\mathrm{CV}\end{array}$ \\
\hline Uniaxial compression & 30 & 60 & 8 & $\begin{array}{l}47.9 \\
0.18\end{array}$ & $\begin{array}{l}10.1 \\
0.30\end{array}$ & $\begin{array}{l}0.14 \\
0.18\end{array}$ \\
\hline Indirect tension & 30 & 15 & 11 & $\begin{array}{c}4.6 \\
0.27 \\
\end{array}$ & & \\
\hline
\end{tabular}

$E$ : tangential Young's modulus at the stress level of 50\%. $v$ : Poisson's ratio. Ave: average value. CV: coefficient of variation

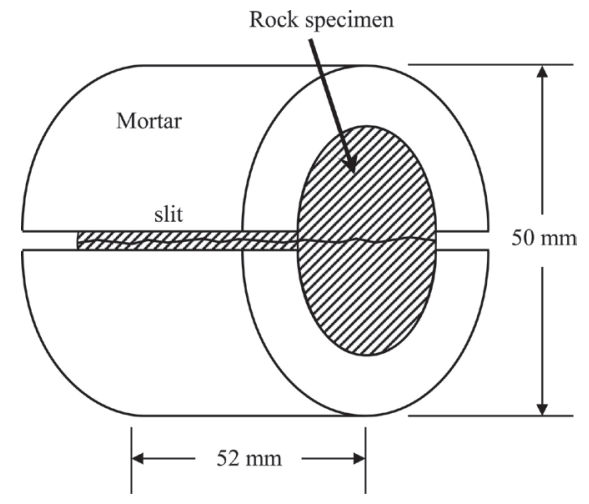

Fig.1 Specimen split by indirect tension test.

現場から採取した試料岩石は比較的もろく，試験片を整形する ことがむずかしかったので，ボーリングした直径 $30 \mathrm{~mm}$ のコア を内径 $50 \mathrm{~mm}$ の型枠の中心において, 周りにモルタルを注ぎ込 んで固めた。モルタルには細骨材を混ぜ，水セメント比 0.5 とし て, 打ち込んだ後に実験室で湿布養生した。養生後の一軸圧縮強 度は $30 \mathrm{MPa}$ 以上であった。モルタルが固まった後に, 型枠を取 り外して, 長さ $50 \mathrm{~mm}$ 強にダイヤモンド鋸で切断して円柱形試 験片を作成した。こうしてできた試験片は，平均值で直径 $50 \mathrm{~mm}$ ×長さ $52 \mathrm{~mm}$ であった。さらにモルタルの影響を取り除くため に, Fig. 1 に示すように, 試験片の両側に金鋸で幅 $1 \mathrm{~mm}$ 強の切 れ目を入れた。すべての試験片の切れ目の寸法を測定して有効せ ん断面積を計算した。有効せん断面の平均值は, 幅 $25 \mathrm{~mm} \times$ 長 さ $52 \mathrm{~mm}$ であった。

亀裂の入った試験片を作成するために，ボーリングして得たコ アを圧裂引張試験で 2 分割し, これを他の試験片と同様に, 型枠 中でモルタルで固めて試験に使用した。試験の直前までゴムバン ドで固定して，亀裂面の移動がないようにした。

試験は気乾状態と湿潤状態とでおこなった。気乾状態は, 試験 片の作成が終了したのちに, 温度 $20 \pm 5^{\circ} \mathrm{C}$, 湿度 $65 \pm 15 \%$ に保っ た部屋で 1 週間以上放置してから試験に使用した。また, 湿潤状 態では, 1 週間以上水中に試験片を浸けた後に試験に供した。

一面せん断試験では，油圧ラムで試験片に垂直荷重を加えなが ら, せん断変位を衿じ式のジャッキで与えた。垂直方向とせん断 方向との荷重は, 歪ゲージ式のロードセルで測定した。せん断変 位は, 歪ゲージ式の変位計で測定した。亀裂をいれていない試験 片のせん断荷重一変位曲線は, はじめは緩やかに立ち上がり, 変 位 $0.5 \mathrm{~mm}$ 前後でピーク荷重をとった。その後は急激に荷重が低 下したが, 変位が $1 \mathrm{~mm}$ 以上になると荷重の低下は緩やかになっ た。試験で得たせん断荷重一変位曲線から, ピーク荷重の他に変 位が 1.0, 1.5, $2.0 \mathrm{~mm}$ おける荷重を測定した。この 3 地点での荷 重の平均值を, 有効せん断面積で割った值を, 以下では残留強度

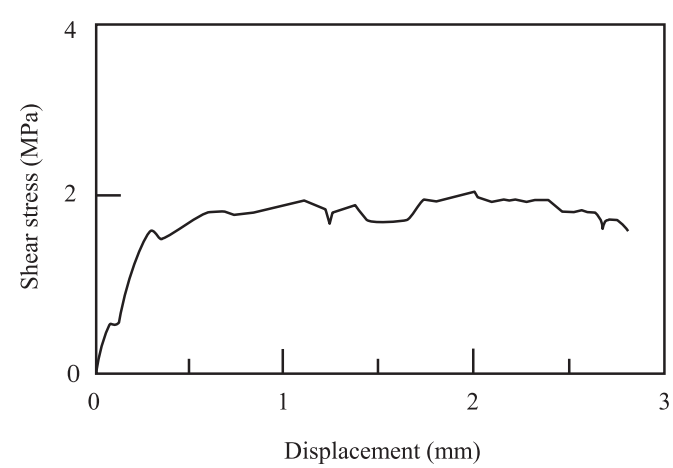

Fig.2 Shear stress-displacement curve for split sample at normal stress $=2 \mathrm{MPa}$.

と称する。なお, 圧裂引張試験であらかじめ亀裂をいれたすべて の試験片では, Fig. 2 に示すようにピーク荷重があらわれなかっ たので,この場合には残留強度のみを示した。

\section{3. 試 験 結 果}

\section{$3 \cdot 1$ ピーク強度と残留強度}

Fig. 3 (a) に, 気乾状態のせん断強度 (以下ではピーク強度と称 する ) $\tau$ と垂直応力 $\sigma$ との関係を示す。一般論でいえば, 本論文 の目的は $\tau$ と $\sigma$ を考慮した二次元分布関数 $f(\tau, \sigma)$ を求めることに 帰着するが, 若干の試行錯誤と物理的な考察に基づいて, 次に記 すような, ごく簡単な手法で試験結果を整理してみることにした。

Fig. 3 (a)の実線は最小二乗法で求めた回帰直線で, 次式で表す ことができる。

$$
\tau=c+\mu \sigma
$$

この場合には, (1) 式の内部摩擦係数 $\mu$ は 0.99 となり, 内部摩擦 角に換算すれば $45^{\circ}$ となる。また, 粘着力 $\mathrm{c}$ は $4.31 \mathrm{MPa}$ となった。 図からわかるように, データは相当にばらつき $\tau$ と $\sigma$ の相関係数 は 0.53 となった。Fig. 3 (b) には, 気乾状態の残留強度と垂直応 力との関係を示寸が, 最小二乗法で近似した $\mu$ は 0.93 と若干小 さくなる。 $c$ は $1.36 \mathrm{MPa}$ で, ピーク強度の $1 / 3$ 弱となった。相関 係数は 0.81 と, かなり向上した。なお前章で述べたように, こ の相関係数は 3 地点での残留強度の平均值に対寸る值である。変 位が 1.0， 1.5, $2.0 \mathrm{~mm}$ における残留強度から同様に相関係数を 求めたところ, それぞれ $0.75,0.81,0.84$ と変位が増大すること によって，相関係数が増大する傾向がみられた。

その他の条件での結果を Table 2 (a) と Fig. 4 とに示す。湿潤 状態のピーク強度 (Wet Peak) では, 気乾状態のピーク強度 (Dry Peak）と比較して, $\mu$ と $c$ が若干低下した。また, この場合の相 関係数は 0.65 であり, やはり相当にデータはばらつくが, 気乾 状態のピーク強度と比較すれば，若干ではあるが相関が向上し 


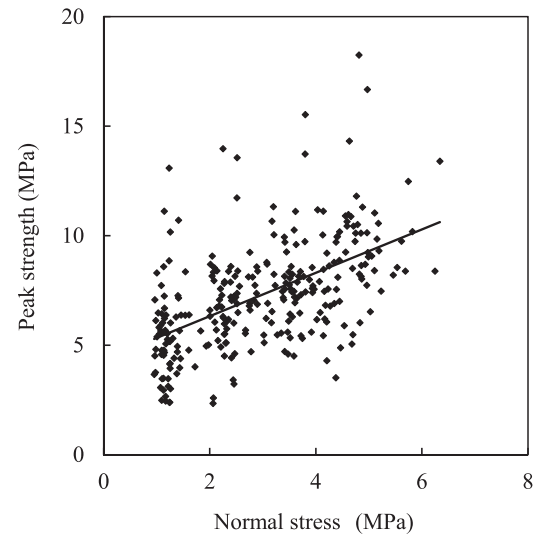

(a) Peak strength

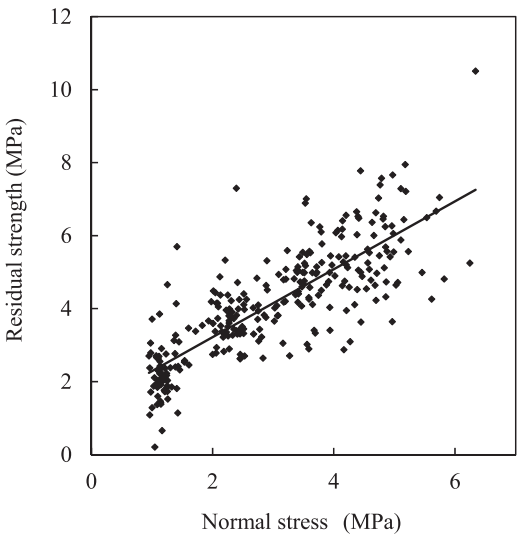

(b) Residual strength

Fig.3 Increase of peak and residual strengths in direct shear tests for air-dried specimens.

Table 2 Parameter for the regression line and standard deviation SD of $\Delta \tau$.

(a) Straight regression line (Eq.1) for red shale. $\mu$ and $c$ are the coefficient of internal friction and cohesion, respectively.

\begin{tabular}{cccccc}
\hline & $\begin{array}{c}\text { Number of } \\
\text { specimens }\end{array}$ & $\mu$ & $\begin{array}{c}c \\
(\mathrm{MPa})\end{array}$ & $\begin{array}{c}\text { Correlation } \\
\text { coefficient }\end{array}$ & $\begin{array}{c}\mathrm{SD} \text { of } \Delta \tau \\
(\mathrm{MPa})\end{array}$ \\
\hline Dry Peak & \multirow{2}{*}{290} & 0.99 & 4.34 & 0.54 & 2.11 \\
Dry Resi & & 0.93 & 1.36 & 0.81 & 0.92 \\
\hline Wet Peak & \multirow{2}{*}{80} & 0.85 & 3.65 & 0.65 & 1.31 \\
Wet Resi & & 0.66 & 0.76 & 0.81 & 0.62 \\
\hline Dry Split & 27 & 0.66 & 0.47 & 0.92 & 0.46 \\
\hline
\end{tabular}

(b) Parabolic regression line (Eq.4) for red shale. $a$ and $b$ are the constants in Eq. 4.

\begin{tabular}{cccccc}
\hline & $\begin{array}{c}\text { Number of } \\
\text { specimens }\end{array}$ & $a$ & $b$ & $\begin{array}{c}\text { Correlation } \\
\text { coefficient }\end{array}$ & $\begin{array}{c}\text { SD of } \Delta \tau \\
(\mathrm{MPa})\end{array}$ \\
\hline Dry Peak & 290 & 4.76 & 0.38 & 0.55 & 2.12 \\
Dry Resi & & 1.94 & 0.69 & 0.80 & 0.91 \\
\hline Wet Peak & \multirow{2}{*}{80} & 4.13 & 0.38 & 0.67 & 1.31 \\
Wet Resi & & 1.20 & 0.74 & 0.83 & 0.62 \\
\hline Dry Split & 27 & 0.93 & 0.87 & 0.93 & 0.46 \\
\hline
\end{tabular}

(c) Straight regression line (Eq.1) for Sanjome andesite in dry conditions. $\mu$ and $c$ are the coefficient of internal friction and cohesion, respectively.

\begin{tabular}{cccccc}
\hline & $\begin{array}{c}\text { Number of } \\
\text { specimens }\end{array}$ & $\mu$ & $\begin{array}{c}c \\
(\mathrm{MPa})\end{array}$ & $\begin{array}{c}\text { Correlation } \\
\text { coefficient }\end{array}$ & $\begin{array}{c}\text { SD of } \Delta \tau \\
(\mathrm{MPa})\end{array}$ \\
\hline 0.05Peak & 16 & 1.02 & 17.28 & 0.99 & 1.36 \\
0.5Peak & 16 & 1.03 & 19.02 & 0.98 & 1.77 \\
5Peak & 16 & 1.02 & 19.98 & 0.98 & 1.94 \\
All Peak & 48 & 1.03 & 18.74 & 0.98 & 2.07 \\
\hline 0.05Resi & 16 & 0.89 & 2.65 & 0.98 & 1.48 \\
0.5Resi & 16 & 0.92 & 1.47 & 0.99 & 1.21 \\
5Resi & 16 & 0.93 & 1.58 & 0.98 & 1.75 \\
All Resi & 48 & 0.91 & 1.90 & 0.98 & 1.50 \\
\hline
\end{tabular}

た。湿潤状態の残留強度 (Wet Resi) では, $\mu$ が 0.66 と気乾状態 (Dry Resi) と比較して大幅に低下した。 $c$ も $0.76 \mathrm{MPa}$ となり, 湿 潤状態のピーク強度の場合と比較して $1 / 5$ 近くまで低下した。相 関係数は 0.81 であり, これは気乾状態の残留強度の場合と同じ

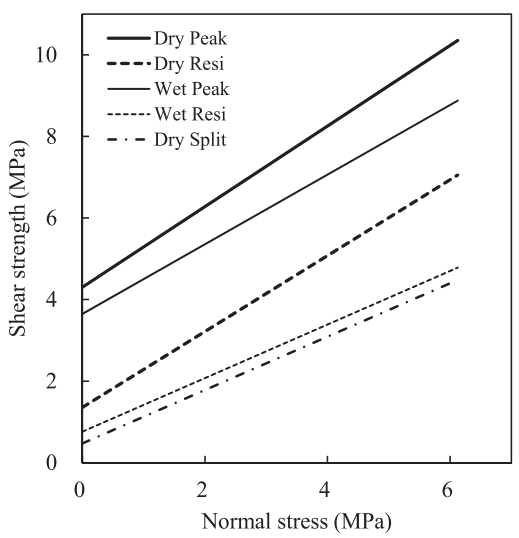

Fig.4 Regression lines on shear strength and normal stress diagram.

值となった。圧裂引張試験で作った亀裂面に沿って滑らせた場合 (Dry Split) には，前述のように荷重のピーク值はあらわれなかっ たので, 残留強度のデータのみ整理をした。この場合の $\mu$ は 0.66 であり，湿潤状態の残留強度の場合と同じ值となった。ただし， $c$ は 0.47MPa となり, 湿潤状態の残留強度の場合と比較して, さ らに小さくなった。残留強度と垂直応力との相関係数は 0.92 と かなり高い值となった。

\section{$3 \cdot 2$ ピーク強度および残留強度の残差}

ピーク強度や残留強度と垂直応力とのデータを得て, 両者の関 係を調べることは，これまでにもおこなわれてきた。特に両者に (1) 式をあてはめて，3・1 節でおこなったように，内部摩擦係数， 粘着力をもとめ, さらに相関係数をもとめることは, しばしばお こなわれてきた ${ }^{9,10)}$ 。しかしながら，このような最小二乗法あ るいは別の手法による近似直線 (場合によっては近似曲線) への あてはめ計算は, データのばらつきやデータの分布関数を明らか にするものではない。データのばらつき方について検討するには, 何らかの形で, 測定した各データと回帰直線との差を求めて, そ の差について議論をする必要がある。

本論文では, 次式から計算したピーク強度および残留強度の残 差 $\Delta \tau$ について検討することにした。

$$
\Delta \tau=\tau-\tau_{\mathrm{m}}=\tau-(c+\mu \sigma)
$$

て はピーク強度あるいは残留強度の測定值である。最小二乗法に より求めた回帰直線の式に, $\sigma$ の測定值を代入して求めた值を 


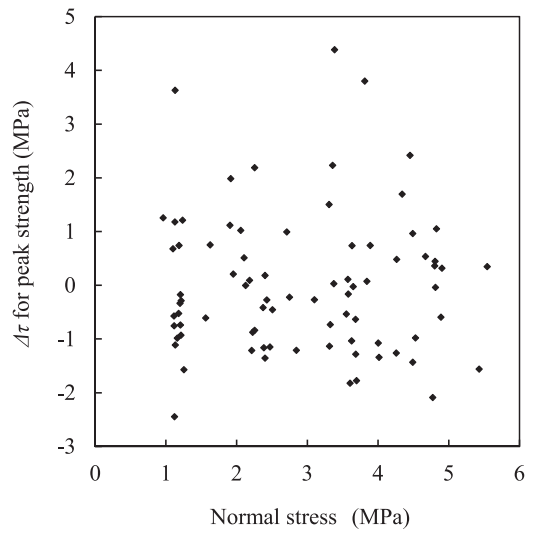

Fig.5 $\Delta \tau$ for peak strength of wet specimens.

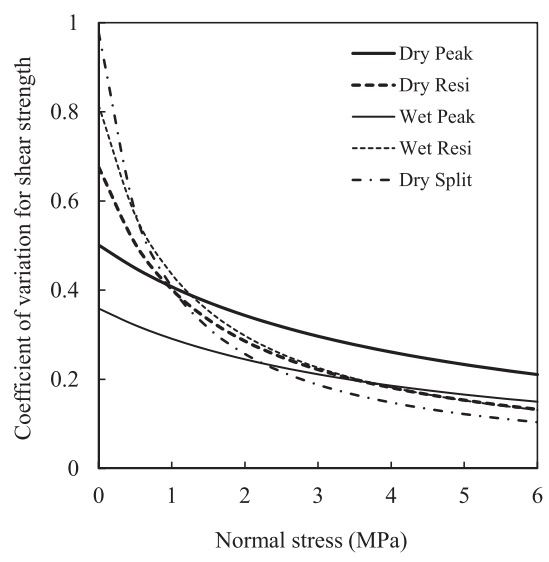

(a) Red shale

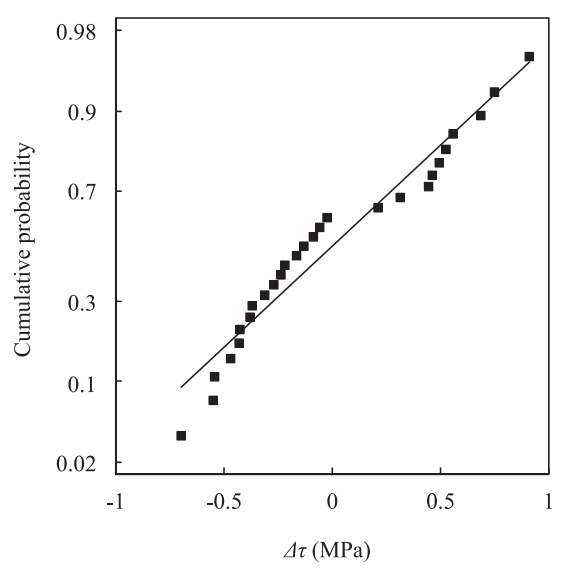

Fig.6 Normal probability plot of $\Delta \tau$ for split specimens.

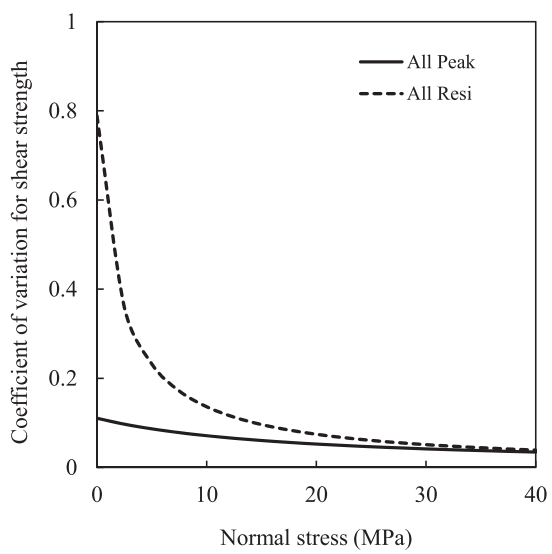

(b) Sanjome andesite

Fig.7 Relation between the coefficient of variation for shear strength and normal stress

$\tau_{\mathrm{m}}$ とした。なお，計算で使用した回帰直線の $c$ と $\mu$ は Table 2 (a) に示した通りである。

Fig. 5 に, 湿潤状態のピーク強度の場合を示す。図よりわかる ように, 垂直応力の変化とともに残差が増加したり減少したりす る傾向は見られなかった。念のため, 垂直応力が $1 \sim 2 \mathrm{MPa}$ ( デー 夕数 22), $2 \sim 3 \mathrm{MPa}$ (同 18), $3 \sim 4 \mathrm{MPa}$ (同 20), $4 \sim 5 \mathrm{MPa}$ ( 同 17) の 4 つの範囲にわけて, それぞれの範囲における $\Delta \tau$ の標 準偏差を求めたところ，1.3，0.96，1.7，1.2 MPa となり一定の傾 向は見られなかった。他の条件でもほぼ同様の結果が得られ, こ れからわかるように, 今回行った試験の範囲内では, 垂直応力 $\sigma$ によらず残差 $\Delta \tau$ のばらつきはほぼ一定といえる。

残差のばらつきは垂直応力と無関係であることがわかったの で,この残差のばらつきに正規分布を当てはめてみた。Fig. 6 に, 気乾状態で亀裂の入った試験片の結果を正規確率紙にプロットし た例を示す。データ点はほぼ直線になり, 残差は正規分布にほぼ 従うことがわかる。同様に各条件下での残差を正規確率紙にプ ロットしたところ，いずれの条件でもほぼ直線になった。Table 2 (a)に各条件での残差の標準偏差をまとめた。

以上の結果より, 任意の垂直応力のもとでのせん断強度のばら つきを推定することができる。 $\mu$ を試験片によらない一定值とみ な寸と, 垂直応力が $\sigma$ での強度の変動係数は, 残差の標準偏差 を $\tau_{\mathrm{m}}$ で割ることで求められる。このようにして求めた強度の変 動係数と垂直応力の関係を Fig. 7 (a) に示した。気乾状態, 湿潤 状態, 亀裂女りの場合の残留強度の標準偏差は, 気乾状態や湿潤
状態でのピーク強度の標準偏差に比べて小さかったが, $c$ も小さ かったので, $\sigma=0 \mathrm{MPa}$ での強度すなわち粘着力の変動係数は逆 に大きくなった。垂直応力が大きくなるに従って変動係数は低下 し, 残留強度の変動係数を表す破線と鎖線は似た傾向を示した。 垂直応力が大きくなるに従って, ピーク強度の変動係数も低下し たが, 残留強度に比べると低下の程度は緩やかであった。

せん断試験でのピーク強度の結果から, (1) 式により, 一軸圧 縮強度は $2 c\left\{\left(1+\mu^{2}\right)^{0.5}+\mu\right\}$ と推定される。c と $\mu$ として気乾状態 での值を用いると, 一軸圧縮強度は $20.7 \mathrm{MPa}$ となった。Table 1 に示した一軸圧縮試験での強度に比べてかなり小さいが, これは, 一軸圧縮試験とは違い, せん断試験には整形が困難な試験片も用 いたためと考えられる。なお, $\mu$ を一定と夕なすと, せん断試験 結果から推定した一軸圧縮強度 $\left(2 c\left\{\left(1+\mu^{2}\right)^{0.5}+\mu\right\}\right)$ の変動係数は 粘着力の変動係数と計算上は一致する。

\section{4. 考察}

\section{$4 \cdot 1$ あてはめ曲線}

議論をわかりやすくするために, 得られた試験結果のあてはめ 曲線として (1) 式の場合についてのみ説明してきた。実際には, 指数関数, 対数関数, 双曲線関数などいろいろな曲線について検 討したが，その内で次式の場合について結果を述べておく。

$$
\tau=a \sigma^{b}
$$

最小二乗法で求めた回帰曲線の $a$ と $b$ の值を Table 2 (b) に示した。 


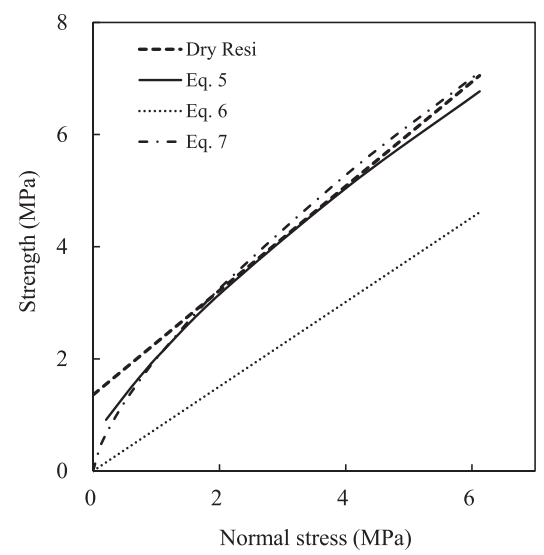

Fig.8 Regression line of residual strength for air-dried samples.Shear strength for fractured rock was calculated with Eq. 5.Curves for long-term strength were calculated with Eq. 6 and Eq. 7.

いずれの場合にも，試験結果は $\tau-\sigma$ 線図上でわずかに上に凸 となっているので, $b$ の值は 1 以下となった。気乾状態と湿潤状 態におけるピーク強度の $b$ の值が, 他と比較して小さかったのは, 縦軸の切片が実際はある程度の大きさを持つからと思われる。一 方, 縦軸の切片がもっとも小さいとおもわれる亀裂をあらかじめ いれた試験片では， $b$ の值が 0.87 と表中で最大となった。相関係 数も同じ表に示したが，いずれも Table 2 (a) に示した回帰直線の 場合とほぼ同じとなった。なお，ここでは便宜上，決定係数の平 方根を相関係数とした。

(3)式を用いた場合の残差は次式であらわされる。

$$
\Delta \tau=\tau-\tau_{\mathrm{m}}=\tau-a \sigma^{b}
$$

この場合にも, 残差のばらつきは垂直応力と無関係であった。回 帰直線の場合と同じように, 残差の標準偏差を Table 2 (b) に示し たが，Table 2 (a) に示した回帰直線の場合とほぼ同じ值となった。

Barton ${ }^{11,12)}$ がまとめた式のうちで, 亀裂を有する岩石 (fractured rock) に対する試験結果のあてはめ曲線は次式となる。

$$
\begin{aligned}
& \tau=\sigma \tan \phi \\
& \text { ただし }, \phi[\mathrm{deg}]=20 \log _{10}\left(\frac{\sigma_{\mathrm{c}}}{\sigma}\right)+30
\end{aligned}
$$

ここで， $\sigma_{\mathrm{c}}$ は一軸圧縮強度， $\sigma$ は垂直応力である。

(5) 式中の $\sigma_{\mathrm{c}}$ として, 今回の気乾状態の赤色頁岩の一軸圧縮強 度である $47.9 \mathrm{MPa}$ を代入して計算した結果を Fig. 8 に示す。なお, (5) 式は $\sigma$ がある程度以上に大きくなると， $\phi$ が負となり意味を 持たない。同じ図には, 気乾状態の残留強度からもとめた回帰直 線もプロットしておいたが，垂直応力が $2 \mathrm{MPa}$ 以上では，(5) 式 と回帰直線とはよく一致する。今回のせん断試験の結果は, 亀裂 を有する岩石の標準的な值と, 少なくとも大きくはかけ離れてい ないと考える。

\section{$4 \cdot 2$ 地圧の最大値との関係}

大久保ら ${ }^{13)}$ は, 測定された地圧の最大主応力と最小主応力を 用いて, Mohrの応力円を描いた。その結果, $\tau-\sigma$ 線図上に次 式に基づく直線を描くと, 多くの応力円がその直線の下にくるこ とを指摘した。

$$
\tau=0.75 \sigma
$$

また最近になって，新たな地圧測定結果を加えて検討して，次式 に修正した ${ }^{14)}$ 。

$$
\tau=2 \sigma^{0.7}
$$

(6) 式と (7) 式を Fig. 8 に描いた。図に示した範囲内では, (7) 式の 方が大きな值となるが，横軸が $26 \mathrm{MPa}$ 付近で両式は交わり，そ れ以降は (6) 式の方が大きな值となる。これは, 大久保ら ${ }^{14)}$ で 新たなデータを追加したところ, 最大と最小の主応力の平均值が 概ね $20 \mathrm{MPa}$ よりも小さい範囲内で，(6) 式より大きな地圧の測定 データがみつかったためである。また, 最大と最小の主応力の平 均值が概ね $40 \mathrm{MPa}$ よりも大きな範囲では，(6) 式より小さな值を とる (7) 式でよいことを確認したためである。大久保ら ${ }^{13,14)}$ は, この整理結果の解釈の一つとして, 測定された地圧は少なくとも 工学的な時間尺度では安定であまり変化しない状況にあり, この 状態では岩盤（岩石）の破壞は進まないと考えて，(7) 式を長期強 度と称した。

最近提案した (7) 式について考察してみる。この式から描かれ る曲線は，偶然かもしれないが，Fig. 8 に示すように，垂直応力 が $6 \mathrm{MPa}$ までの範囲内で, 本研究の気乾状態の残留強度の回帰 直線, Barton ${ }^{11)}$ が提案した (5) 式とよく一致する。そこで考えら れる仮説が，“岩盤には亀裂を含む弱部が多数あり，その部分の 強度以上の地圧は生じない。弱部の強度は (7) 式とあまり変わら ない。”である。この仮説の是非については今後検討していきたい。

\section{$4 \cdot 3$ 他の岩石の結果との比較}

Fukui et al. ${ }^{9)}$ は, 三城目安山岩を使用して一面せん断試験をお こなった。試験片は気乾状態で, 直径と長さはともに $50 \mathrm{~mm}$ で ある。 $0.05,0.5,5 \mu \mathrm{m} / \mathrm{s}$ の 3 通りの変位速度で試験をおこない, 強度の載荷速度依存性を検討している。また, 垂直応力は, 10, 20, 30, $40 \mathrm{MPa}$ の 4 通りとした。なお, 同一条件での試験数は 4 である。ピーク強度の他に, 変位が $2 \mathrm{~mm}$ のころで測定した残 留強度も測定している。このデータに (1) 式を当てはめて計算し た結果を Table 2 (c) に示す。 0.05 Peak としてあるのは, 変位速度 が $0.05 \mu \mathrm{m} / \mathrm{s}$ の時のピーク強度である。0.05 Resi としてあるのは, 残留強度の場合である。また, All Peak と All Resi は, それぞれ の変位速度および鉛直応力の場合を含めたすべてのピーク強度と 残留強度を用いて計算した場合であり，データ数はともに $4 \times 3$ $\times 4=48$ である。ただし，変位速度が変わるとピーク強度も変わ るので，次式 ${ }^{9)}$ を用いて $0.5 \mu \mathrm{m} / \mathrm{s}$ での值 $\tau_{0.5}$ に換算した後に $c$ と $\mu$ を求めた。

$$
\tau_{0.5}=\tau_{\mathrm{R}}\left(\frac{0.5}{R}\right)^{\frac{1}{n+1}}
$$

ここで， $\tau_{\mathrm{R}}$ は変位速度 $R(\mu \mathrm{m} / \mathrm{s})$ での強度であり, $n$ は試験で求め られた值 38 を用いた。残留強度には載荷速度依存性が認められ なかったので補正は行わなかった。

表よりわかるように，変位速度が変わっても，ばらつき方には 大きな変化は認められなかったので, All Peak と All Resiについ てみていく。ピーク強度に関しては $\mu$ が 1.03 であり, 赤色頁岩 $($ 気 乾状態のピーク強度) の場合とほとんど変わらない。c に関して は $18.74 \mathrm{MPa}$ であり赤色頁岩の 4 倍以上となった。相関係数は 0.98 と非常に高かった。これまでと同様に残差を求めたところ, 残差 は垂直応力と無関係であり, 正規分布にほぼ従うことがわかった。 残差の標準偏差を表に示したが，ピーク強度での值は赤色頁岩の 気乾状態でのピーク強度での值と同程度であった。残留強度での 值は赤色頁岩の気乾状態での残留強度での值の約 1.5 倍であった。

赤色頁岩と同様に残差の標準偏差を $c+\mu \sigma$ で割って, 垂直応力 が $\sigma$ での強度の変動係数を求めて Fig. 7 (b) に示した。グラフの 傾向は赤色頁岩と似ており, 垂直応力の増加とともにピーク強度 
と残留強度とも変動係数は低下したが，ピーク強度の低下の方が 緩やかであった。定量的に見ると, 残留強度の変動係数は赤色頁 岩と三城目安山岩とで大差はなかったが, ピーク強度の変動係数 は三城目安山岩の方が小さかった。

Shin et al. ${ }^{10)}$ では, 安山岩, 凝灰岩, 砂岩, 泥岩の一軸圧縮試験, 圧裂引張試験，一軸引張試験およびクリープ試験の結果を整理し て, 気乾状態と湿潤状態での強度分布を検討している。その結果 によれば，強度の変動係数は気乾と湿潤状態とでほとんど変わら なかったという。今回の赤色頁岩のピーク強度に関しては, 湿潤 状態での粘着力の変動係数は，気乾状態での值の約 $70 \%$ となっ た。Shin et al. ${ }^{10)}$ では強度そのものを対象とした值であるのに対 して, 今回は強度の残差から推定した值であること, また, 本研 究とは違い Shin et al. ${ }^{10)}$ ではき裂の少ない試料を用いていること を指摘しておきたい。

Shin et al. ${ }^{10)}$ では, 三軸圧縮試験結果についても検討している。 この三軸圧縮試験はモールの応力線図に応力円を描くと, その包 絡線より (1) 式の関係が得られることからもわかるように, 一面 せん断試験と密接に結びついた試験である。しかしながら，三軸 圧縮試験と一面せん断試験とは, 山口・西松 ${ }^{1)}$ が指摘するとお りに原理の異なる試験方法であり, 試験結果のばらつきを定量的 に議論することは簡単ではない。そこで，以下では定性的に三軸 圧縮試験の結果と比較してみる。Shin et al. ${ }^{10)}$ で, 新第三紀の堆 積岩 (neogene sedimentary rocks) については, 三軸圧縮強度の変 動係数が，周圧の増加に伴い減少すると述べている。この結果は 今回の一面せん断試験で得られた結果と矛盾しない。また, 山口・ 大久保 ${ }^{8)}$ もこれと類似した結果を, 稲田花崗岩で得ている。一方, 三城目安山岩や田下凝灰岩では, 三軸圧縮強度の変動係数が, 周 圧により変化しなかったとしている。周圧によって強度が上昇す るが, それに比例して強度の標準偏差も大きくなったためである。 これは, 今回の一面せん断試験で得られた結果と異なる。これか らみて, 今回の結果は岩石ごとに異なる可能性があるので, 今後 の継続的な検討が必要とおもわれる。

\section{$4 \cdot 4$ 局所安全率}

鋼などの金属材料と比較して, 岩石の強度は大きくばらつくの で，設計には困難がつきまとう。その一般論を本論文で論ずるこ とは到底できないが, Okubo et al. ${ }^{15)}$ が提案した局所安全率を用 いて, ごく簡単に考察しておく。

（1）式と同じ形の破壊条件を仮定した場合の局所安全率は次式 で与えられる。

$$
S_{\mathrm{f}}=\frac{\sigma_{\mathrm{c}} \sigma_{\mathrm{t}}}{\sigma_{1} \sigma_{\mathrm{t}}-\sigma_{3} \sigma_{\mathrm{c}}}=\frac{2 c}{\sigma_{1}\left(\sqrt{1+\mu^{2}}-\mu\right)-\sigma_{3}\left(\sqrt{1+\mu^{2}}+\mu\right)} \cdots \cdots
$$

ただし， $\sigma_{1}$ と $\sigma_{3}$ は，最大および最小主応力で， $\sigma_{\mathrm{c}}$ と $\sigma_{\mathrm{t}}$ は，一 軸圧縮強度および引張強度である。（9）式の局所安全率は， $c$ に 比例する。 $3 \cdot 2$ 節での議論と同様に $\mu$ が回帰直線の傾きに等し いと仮定すれば, ある地圧 $\left(\sigma_{1}\right.$ と $\left.\sigma_{3}\right)$ が加わっている場合の $\mathrm{S}_{\mathrm{f}}$ の 変動係数は, $c$ の変動係数と同じになる。 $\Delta \tau$ が正規分布に従えば, $c$ と $\mathrm{S}_{\mathrm{f}}$ も正規分布に従うことになる。

本稿では，一貫して $\mu$ のばらつきは考慮しなかったが，これ は $c$ のばらつきよりも小さいことが想定されたためである。例え ば Shin et al. ${ }^{10)}$ では, 安山岩, 凝灰岩, 砂岩, 泥岩の $c$ と $\mu$ の変
動係数は, それぞれ $0.03 \sim 0.3$ および $0.01 \sim 0.03$ と推定されて いる。 $\mu$ のばらつきも考慮した検討は今後の課題として残されて いる。

\section{5. 結論}

本研究では，これまでの知見が少ないせん断強度のばらつきに ついて，一面せん断試験によって検討した。一面せん断試験で強 度のばらつきを正確に論ずるには多くの試験片を要するので試験 片の作成には工夫をした。すなわち, 試験片をその直径より大き めの型枠にいれて，型枠と試験片との間のすきまにモルタルを流 し込んで固めた。こうすることにより, 表面が滑らかで久けのな い多くの試験片を作成することができた。

一面せん断試験は, 気乾状態と湿潤状態の試験片を用いておこ ない, ピーク強度と残留強度とをもとめた。なお, 圧裂引張試験 であらかじめ亀裂をつくった試験片でも試験をした。その結果， (2) 式より計算されるせん断強度の残差 $\Delta \tau$ は, 全ての試験条件 下で，垂直応力と無関係であることがわかった。Fukui et al. ${ }^{9)}$ は, 三城目安山岩を使用して一面せん断試験をおこなったが，この場 合にもせん断強度の残差は垂直応力と無関係であった。この知 見は重要であり, $\Delta \tau$ のばらつきから粘着力や任意の垂直応力下 でのせん断強度のばらつきを推定することができ, また, ある応 力状態のもとでの局所安全率のばらつきも推定できる可能性があ る。赤色頁岩については, 気乾状態における一面せん断試験での 残留強度の回帰直線が，過去に提案されている亀裂を有する岩石 の破壊条件や長期強度を表す曲線とほぼ一致することを示した。

周圧下での強度とせん断強度のばらつきに関する知見は少な く, 本稿でも両者の関係については定性的に考察するにとどまっ た。データを蓄積して, 両者の関係を詳細に調べることが今後の 重要な課題である。また今回は, 試験結果のばらつきにおよぼす 層理面などの異方性の影響や, あらかじめ亀裂の入った試験片で の湿潤状態での特性は検討しなかったので，今後検討する必要が ある。

謝辞＼cjkstart曹兴惠氏には, 原稿作成に際してお世話になったので, ここに謝意を表する。

\section{References}

1) 山口梅太郎, 西松裕一：岩石力学入門第 3 版, (東京大学出版会, 東京, 1991), pp. 109-115, pp. 148-151.

2) 伊藤洋, 新孝一: 地盤物性值のばらつきとその影響評価一原子力発電所基礎地盤 および周辺斜面の安定性一, 電力中央研究所報告 U87058, (電力中央研究所, 我孫 子, 1988).

3) U. Yamaguchi: Int. J. Rock Mech. Min. Sci., 7 (1970), 209-227.

4) O. Sano, Y. Kudo, K. Furukawa and K. Nakagawa: Journal of Japan Society of Civil Engineers, 388 (1987), 141-150.

5) Y. Kudo,O. Sano, K. Furukawa and K. Nakagawa: Journal of Japan Society of Civil Engineers, 400 (1988), 233-241.

6) S. Okubo and S. Chu: Journal of MMIJ, 110 (1994), 533-538.

7) S. Chu, S. Okubo and K. Fukui: Journal of MMIJ, 111 (1995), 231-237.

8) T. Yamaguchi and S. Okubo: Journal of MMIJ, 116 (2000), 623-629.

9) F. Fukui, S. Okubo and A. Ogawa: Int. J. Rock Mech. Min. Sci., 41 (2004), 1215-1219.

10) K. Shin, S. Okubo, K. Fukui and K. Hashiba: Int. J. Rock Mech. Min. Sci., 42 (2005), 251260.

11) N. Barton: Int. J. Rock Mech. Min. Sci. \&Geomech. Abstr., 13 (1976), 255-279.

12) N. Barton: J. Rock Mech. Geotech. Engng, 5 (2013), 249-261.

13) S. Okubo, K. Fukui and K. Shin: Journal of MMIJ, 115 (1999), 213-218

14) S. Okubo, K. Hashiba and K. Fukui: Journal of MMIJ, 129 (2013), 635-641.

15) S. Okubo, K. Fukui and Y. Nishimatsu: Rock Mech. Rock Engng., 30 (1997), 223-227. 